\title{
PENGARUH KONVERGENSI IFRS, KOMPLEKSITAS AKUNTANSI DAN PROBABILITAS KEBANGKRUTAN PERUSAHAAN TERHADAP MANAJEMEN \\ LABA DENGAN GOOD CORPORATE GOVERNANCE SEBAGAI VARIABEL MODERASI
}

\author{
Tiara Wulandari \\ STIE Pembangunan Tanjungpinang \\ tiarawulandari298@yahoo.co.id
}

\begin{abstract}
Abstrak: Penelitian ini bertujuan untuk mengetahui pengaruh konvergensi IFRS, kompleksitas akuntansi, probabilitas kebangkrutan perusahaan terhadap manajemen laba dengan good corporate governance sebagai variabel moderasi. Sampel dalam penelitian ini adalah perusahaan Manufaktur yang terdaftar di Bursa Efek Indonesia (BEI) tahun 2013-2015. Metode penentuan sampel menggunakan metode purposive sampling. Terdapat 87 perusahaan terpilih sebagai sampel dalam penelitian ini. Teknik analisis yang digunakan adalah moderated regression analysis (MRA). Hasil penelitian ini menunjukkan bahwa (1) konvergensi IFRS berpengaruh negatif terhadap manajemen laba, (2) kompleksitas akuntansi tidak berpengaruh terhadap manajemen laba, (3) probabilitas kebangkrutan perusahaan berpengaruh positif terhadap manajemen laba, (4) komite audit berpengaruh negatif terhadap manajemen laba, (5) komite audit tidak memperkuat pengaruh konvergensi IFRS terhadap manajemen laba, (6) komite audit tidak tidak memperlemah pengaruh kompleksitas akuntansi terhadap manajemen laba, dan (7) komite audit tidak memperlemah pengaruh probabilitas kebangkrutan perusahaan terhadap manjemen laba.
\end{abstract}

Kata Kunci: Konvergensi IFRS, kompleksitas akuntansi, probabilitas kebangkrutan perusahaan, manajemen laba, good corporate governance, komite audit.

Abstract: This research aims to determine the effect of IFRS convergence, accounting complexity, company bankruptcy probability on earnings management with good corporate governance as moderating variable. The sample in this research is a Manufacturing company listed on the Indonesia Stock Exchange (BEI) in 2013-2015. The sampling method using purposive sampling method. There are 87 companies selected as samples in this research. The analysis technique used is moderated regression analysis (MRA). The results of this study indicate that (1) IFRS convergence negative effect on earnings management, (2) accounting complexity has no effect on earnings management. (3) company bankruptcy probability positive effect on earnings management. (4) audit committee negative effect on earnings management. (5) audit committee does not amplify the effect of IFRS convergence on earnings management. (6) audit committee does not weaken the effect of accounting complexity on earnings management. (7) audit committee does not weaken the effect of company bankruptcy probability on earnings management.

Keywords: IFRS convergence, accounting complexity, company bankruptcy probability, earnings management, corporate governance, audit committee.

\section{PENDAHULUAN}

Perusahaan yang go public diwajibkan untuk menyampaikan laporan keuangan yang telah disusun sesuai dengan Standar Akuntansi Keuangan dan telah diaudit oleh akuntan publik yang terdaftar di Otoritas Jasa Keuangan (OJK). Standar akuntansi keuangan sebagai pedoman pokok penyusunan dan penyajian laporan keuangan sangat penting agar laporan keuangan lebih 
berguna, dapat dimengerti, dapat diperbandingkan, serta tidak menyesatkan. Sehingga dapat membantu para penentu keputusan dalam mengambil keputusan yang tepat bagi kelangsungan suatu usaha. Sementara itu dalam pengambilan keputusan investasi, investor memerlukan informasi ekonomi dari perusahaan terkait.

Perbedaan standar akuntansi akan menjadi hambatan investasi antar negara, ketika terdapat keseragaman standar akuntansi maka investor atau calon investor di negara lain akan lebih mudah memahami laporan keuangan perusahaan. Hal ini yang mendorong perubahan standar akuntansi keuangan nasional kepada standar akuntansi keuangan yang baru yakni konvergesi IFRS (International Financial Reporting Standard). Konvergensi IFRS adalah penyesuaian PSAK (Pernyataan Standar Akuntansi Keuangan (PSAK) yang berlaku di Indonesia disesuaikan dengan standar internasional. Diharapkan dengan adanya konvergensi IFRS mampu memberikan pemahaman yang lebih baik dalam mengartikan laporan keuangan dikarenakan semua negara telah mempunyai aturan atau standar yang seragam sehingga tidak terdapat persepsi yang keliru dalam menginterpretasikan laporan keuangan.

Jika dilihat dari sisi akuntansi, konvergensi IFRS meningkatkan kualitas pelaporan laporan keuangan ke pasar modal (Cahyati, 2011). Selain itu penggunaan praktik akuntansi yang sama di berbagai negara akan memudahkan investor dalam mendeteksi manajemen laba. Standar IFRS yang akan berdampak pada semakin sedikitnya pilihan-pilihan metode akuntansi yang dapat diterapkan dan pengungkapan yang lebih banyak dan rinci seperti berbasis prinsip, lebih pada penggunaan nilai wajar, sehingga akan meminimalisir praktik-praktik kecurangan akuntansi, seperti manajemen laba. Jadi secara teoritis konvergensi IFRS mengurangi manajemen laba yang dilakukan perusahaan (Cahyati, 2011).

Globalisasi membuka kesempatan perkembangan bisnis yang begitu pesat sehingga mendorong pemilik atau manajemen perusahaan untuk mengembangkan usahanya dengan strategi bisnis baik jangka panjang maupun jangka pendek. Salah satu caranya adalah dengan penggabungan beberapa usaha yang akhirnya mempengaruhi jumlah anak perusahaan yang dimiliki. Bentuk penggabungan usaha yang sering dilakukan adalah merger dan akusisi saham dimana strategi ini dipandang sebagai salah satu cara untuk mencapai beberapa tujuan yang lebih bersifat ekonomis dan jangka panjang. Hubungan yang timbul dari akuisisi saham disebut hubungan induk dan anak perusahaan. Induk perusahaan (parent company) adalah perusahaan yang mengendalikan perusahaan lain yang disebut sebagai perusahaan anak (subsidiary).

Semakin banyak entitas anak yang dimiliki oleh suatu perusahaan akan membuat struktur organisasi semakin kompleks, karena 
diperlukan konsolidasi laporan keuangan antara entitas induk dan anak. Akibatnya proses pelaporan keuangan oleh entitas induk menjadi semakin kompleks. Di sisi lain perbedaan treatment akuntansi antara entitas anak akan berkontribusi ke manajemen pendapatan, biaya, serta transaksi (Widyawati dan Anggraita, 2013). Manajemen perusahaan dengan segmen bisnis yang beragam diduga pula memiliki peluang untuk melakukan manajemen laba. Hal ini dikaitkan dengan kompleksitas organisasi yang meningkatkan asimetri informasi antara manajer dan investor. Manajer memiliki peluang untuk mengambil keputusan yang memaksimalkan dirinya sendiri (Indraswari, 2010).

Selain itu, globalisasi juga meningkatkan kompetisi bagi perusahaan dan organisasi dalam dunia bisnis untuk berusaha menjadi yang terbaik dengan menerapkan proses bisnis yang lebih efektif dan efesien. Untuk bisa berkompetisi dengan baik perusahaan membutuhkan dana untuk terus melakukan inovasi serta mengelola dan memposisikan perusahaan lebih unggul dibanding pesaingnya. Keadaan tersebut membuat persaingan bisnis global dari tahun ke tahun semakin besar dan perusahaan yang berupaya memasuki bisnis global semakin banyak. Dengan demikian, perusahaan dalam jangka panjangnya bertujuan untuk mempertahankan kelangsungan hidup (going concern) usahanya. Kelangsungan hidup usaha selalu dihubungkan dengan kemampuan manajemen dalam mengelola perusahaan agar tetap bertahan hidup.

Banyaknya biaya pengeluaran kadang tidak disertai dengan kemampuan perusahaan untuk menutup biaya tersebut karena mungkin daya saing pasar global yang terlalu kuat (Wulandari dan Lastanti, 2015). Pada akhirnya, kondisi keuangan yang melemah membuat perusahaan tersebut dipertanyakan status going concern perusahaan dan bagaimana probabilitas kebangkrutannya. Status perusahaan yang dalam kondisi keuangan yang lemah, serta dipertanyakan status going concern, hal ini membuat manajemen mungkin akan melakukan tindakan manajemen laba untuk menutupi kondisi perusahaan (Widyawati dan Anggraita, 2013).

Hasil penelitian-penelitian sebelumnya mengenai konvergensi IFRS, kompleksitas akuntansi, probabilitas kebangkrutan perusahaan dan manajemen laba memang sudah ada, akan tetapi hasilnya masih belum konsisten dan adanya research gap, sehingga memotivasi peneliti untuk melakukan penelitian lebih lanjut. Untuk membedakan penelitian ini dengan penelitian sebelumnya penelitian ini menggunakan variable moderasi yaitu Good Corporate Governance. Good Corporate Governance dalam penelitian ini diproksikan dengan komite audit. Komite audit bertugas untuk mendukung fungsi pengawasan terhadap manajemen, hal ini dilakukan supaya manajemen tidak bersifat oportunis. Semakin 
banyaknya anggota komite audit akan meningkatkan kinerja komite audit tersebut. Hal ini akan mengakibatkan fungsi pengawasan semakin meningkat, sehingga kualitas pelaporan yang dilakukan oleh manajemen terjamin. Lin et al (2006) membuktikan bahwa semakin besar ukuran komite audit maka kualitas pelaporan keuangan semakin terjamin. Sehingga besarnya ukuran komite audit dapat meminimalisasi terjadinya manajemen laba. Dengan adanya pengawasan oleh komite audit diharapkan mampu memoderasi pengaruh konvergensi IFRS, kompleksitas akuntansi dan probabilitas kebangkrutan perusahaan terhadap manajemen laba. Penelitian ini juga menambahkan variabel kontrol, yaitu ukuran perusahaan dan profitabilitas.

\section{Tujuan Penelitian}

Tujuan dari penelitian ini adalah : 1) Untuk memperoleh bukti empiris pengaruh profitabilitas terhadap nilai perusahaan; 2) Untuk memperoleh bukti empiris pengaruh leverage terhadap nilai perusahaan; 3 ) Untuk memperoleh bukti empiris bahwa penerapan good corporate governance dapat memperkuat profitabilitas terhadap nilai perusahaan, 4) Untuk memperoleh bukti empiris bahwa penerapan good corporate governance dapat memperlemah pengaruh leverage terhadap nilai perusahaan; 5) Untuk memperoleh bukti empiris bahwa kebijakan dividen dapat memperkuat pengaruh profitabilitas terhadap nilai perusahaan; 6)
Untuk memperoleh bukti empiris bahwa kebijakan dividen dapat memperlemah pengaruh leverage terhadap nilai perusahaan

\section{METODE PENELITIAN}

Metode yang digunakan dalam penelitian ini adalah metode kuantitatif kausal. Menurut Sugiyono (2014) metode penelitian kuantitatif dapat diartikan sebagai metode penelitian yang berlandaskan pada filsafat positivisme, digunakan untuk meneliti pada populasi atau sampel tertentu, pengumpulan data menggunakan instrumen penelitian, analisis data bersifat kuantitatif/statistik, dengan tujuan untuk menguji hipotesis yang telah ditetapkan.

Populasi dalam penelitian ini adalah semua perusahaan yang terdaftar di Bursa Efek Indonesia (BEI) dari tahun 2013 sampai dengan tahun 2015. Sedangkan sampel dalam penelitian ini ditentukan dengan menggunakan purposive sampling, yaitu teknik yang digunakan dalam penentuan sampel yang dipilih berdasarkan kriteria tertentu dan berdasarkan pertimbangan tertentu yang disesuaikan dengan tujuan penelitian. Terdapat 87 perusahaan terpilih sebagai sampel dalam penelitian ini.

Metode analisis data dalam penelitian ini menggunakan statistik deskriptif dan model regresi linear berganda dengan menggunakan interaksi atau yang dikenal dengan Moderated Regression Analysis (MRA). Analisis data yang diperoleh dalam penelitian ini akan menggunakan bantuan analisis regresi data panel (pooled data) dengan 
teknologi komputer yaitu program aplikasi Econometric Views (Eviews).

\section{Model Penelitian}

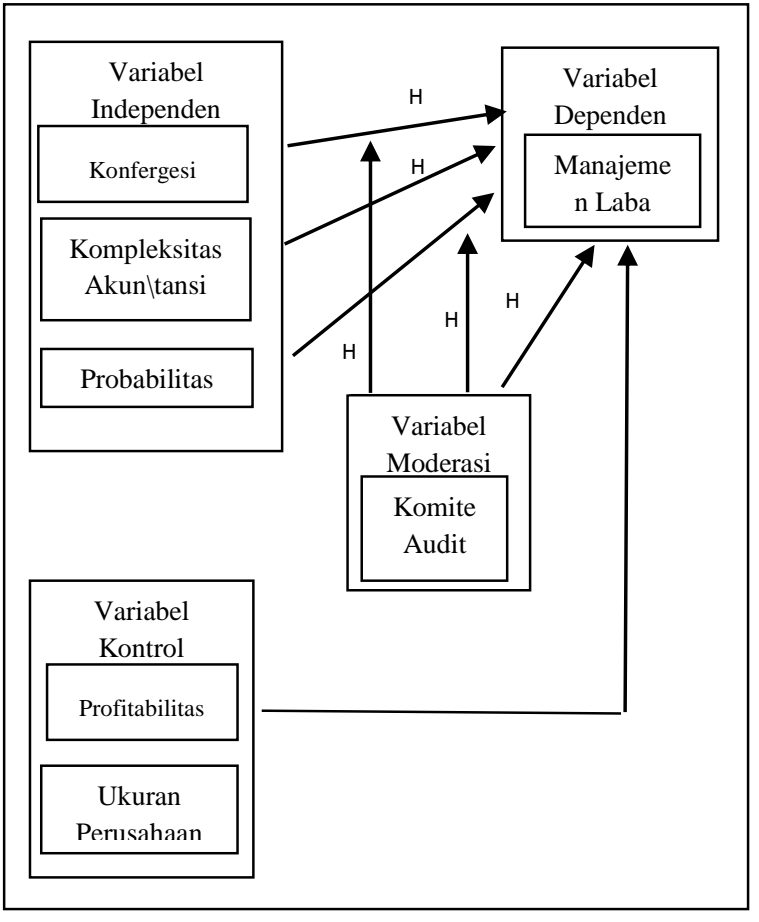

HASIL DAN PEMBAHASAN

\section{Pemilihan Model}

Setelah dilakukan pengujian dengan Chow test, Breusch Pagan Lagrange Multiplier test, dan Hausman test, maka model pengujian yang dipilih dalam penelitian ini yaitu fixed effect model.

\section{Uji Asumsi Klasik}

\section{Uji Normalitas}

Syarat data yang layak untuk diuji adalah data tersebut harus terdistribusi normal. Pengujian ini digunakan untuk menguji apakah data terdistribusi normal atau tidak yang dilakukan dengan menggunakan analisis regresi linier. Model regresi yang baik adalah distribusi data masing-masing variabelnya normal atau mendekati normal. Menurut (Gujarati dan Porter, 2012), uji normalitas bertujuan untuk menguji apakah dalam model regresi variabel pengganggu atau residual memiliki distribusi normal atau tidak.

\begin{tabular}{|c|c|}
\hline $\begin{array}{l}\text { Series: Stand } \\
\text { Sample } 2013 \\
\text { Obsenvations }\end{array}$ & $\begin{array}{l}\text { dardized Residuals } \\
2015 \\
261\end{array}$ \\
\hline Mean & $-3.12 e-18$ \\
\hline Median & 0.002583 \\
\hline Maximum & 0.330078 \\
\hline Minimum & -0.553439 \\
\hline Std. Dev. & 0.077527 \\
\hline $\begin{array}{l}\text { Skewness } \\
\text { Kurtosis }\end{array}$ & $\begin{array}{r}-1.071079 \\
13.29705\end{array}$ \\
\hline $\begin{array}{l}\text { Jarque-Bera } \\
\text { Probability }\end{array}$ & $\begin{array}{l}1202.972 \\
0.000000\end{array}$ \\
\hline
\end{tabular}

Sumber: Hasil pengolahan data dengan Eviews

Grafik 1

Uji Normalitas

\section{Uji Multikolonieritas}

Uji ini dilakukan untuk mengetahui apakah antar variabel independen mengandung korelasi atau tidak. Jika korelasi antar variabel independennya $<0,8$ maka variabel independen IFRS, kompleksitas akuntansi, probabilitas kebangkrutan, komite audit, profitabilitas (ROA), ukuran perusahaan, interaksi IFRS dan komite audit, interaksi kompleksitas akuntansi dan komite audit, dan interaksi probabilitas kebangkrutan dan komite audit tidak terjadi multikolonieritas. Berikut hasilnya: 
Tabel 1

Uji Multikolinieritas

\begin{tabular}{|c|c|c|c|c|c|c|c|c|c|}
\hline Correla & & COMP & & & & & CMPL & IFRS_ & PROB \\
\hline tion & IFRS & LX & PROB & KA & SIZE & ROA & & KA & \\
\hline & 1.00 & & & & & & & & \\
\hline IFRS & 0000 & & & & & & & & \\
\hline $\mathrm{COM}$ & 0.08 & 1.000 & & & & & & & \\
\hline PLX & 9015 & 000 & & & & & & & \\
\hline PRO & 0.05 & 0.040 & 1.000 & & & & & & \\
\hline B & 3565 & 073 & 000 & & & & & & \\
\hline & - & & & & & & & & \\
\hline & 0.07 & 0.141 & 0.130 & 1.000 & & & & & \\
\hline KA & 8823 & 973 & 187 & 000 & & & & & \\
\hline & 0.30 & 0.601 & 0.217 & 0.196 & 1.000 & & & & \\
\hline SIZE & 6017 & 624 & 367 & 956 & 000 & & & & \\
\hline & 0.05 & 0.044 & 40.778 & 0.191 & 0.230 & 1.000 & & & \\
\hline ROA & 7457 & 638 & 863 & 755 & 506 & 000 & & & \\
\hline $\mathrm{COM}$ & & & - & & & - & & & \\
\hline PLX & 0.11 & 0.138 & 0.012 & 0.187 & 0.235 & 0.010 & 1.000 & & \\
\hline $\mathrm{KA}$ & 8852 & 986 & 265 & 887 & 550 & 701 & 000 & & \\
\hline & - & & & & & & - & & \\
\hline IFRS & 0.24 & 0.051 & 0.058 & 0.614 & 0.017 & 0.092 & 0.131 & 1.000 & \\
\hline KA & 4832 & 451 & 554 & 674 & 290 & 862 & 277 & 000 & \\
\hline PRO & & - & - & - & & - & & - & \\
\hline B_K & 0.15 & 0.014 & 0.136 & 0.356 & 0.019 & 0.16 & 0.353 & 0.634 & 1.000 \\
\hline A & 9337 & 438 & 971 & 369 & 471 & 399 & 242 & 051 & 000 \\
\hline
\end{tabular}

Sumber: Hasil pengolahan data dengan Eviews

\section{Uji Heteroskedastisitas}

Uji heteroskedastisitas bertujuan untuk menguji apakah dalam model regresi terjadi ketidaksamaan varian dari residual satu pengamatan ke pengamatan yang lain. Jika varian dari residual satu pengamatan ke pengamatan lain tetap, maka disebut homoskedastisitas dan jika berbeda disebut heteroskedastisitas. Model regresi yang baik adalah model yang tidak terjadi heteroskedastisitas. Untuk menentukan heteroskedastisitas dapat menggunakan uji gletser (Gujarati dan Porter, 2012). Berikut hasilnya:

Tabel 2

Uji Heteroskedastisitas \begin{tabular}{|l|r|}
\hline \multicolumn{2}{|c|}{ Cross-section fixed (dummy variables) } \\
\hline Prob(F-statistic) & 0.000000 \\
\hline
\end{tabular} Sumber: Hasil pengolahan data dengan Eviews

\section{Uji Autokorelasi}

Uji autokorelasi ini bertujuan untuk menguji apakah dalam model regresi linier ada korelasi antar kesalahan pengganggu pada periode $t$ dengan kesalahan pada periode t-1 (sebelumnya). Model regresi yang baik adalah regresi bebas dari autokorelasi. Untuk menentukan autokorelasi dapat menggunakan uji DW (durbin watson). Berikut hasilnya:

Tabel 3

Uji Autokorelasi

\begin{tabular}{|l|r|}
\hline \multicolumn{2}{|c|}{ Cross-section fixed (dummy variables) } \\
\hline Durbin-Watson stat & 2.589004 \\
\hline
\end{tabular}

Sumber: Hasil pengolahan data dengan Eviews

Berdasarkan uji asumsi klasik yang telah dilakukan diatas, maka terdapat uji asumsi klasik yang tidak terpenuhi yaitu heterosedastisitas dan autokorelasi. Sehingga dilakukan transformasi fix effect model dengan menggunakan pendekatan panelcorrected standard errors (PCSE) (Firdaus dan Irawan, 2007), dimana metode ini akan mengatasi masalah heteroskedastisitas dan autokorelasi. Adapun hasilya yaitu:

\section{Tabel 4}

Panel-Corrected Standard Errors

\begin{tabular}{|c|c|c|c|c|}
\hline Variable & Coefficient & Std. Error & t-Statistic & Prob. \\
\hline C & -3.875178 & 0.231706 & -16.72456 & 0.0000 \\
\hline IFRS & -0.003097 & 0.000900 & -3.440654 & 0.0007 \\
\hline COMPLX & -0.007293 & 0.002327 & -3.134135 & 0.0020 \\
\hline PROB & 0.007755 & 0.001602 & 4.839393 & 0.0000 \\
\hline KA & -0.017157 & 0.009551 & -1.796428 & 0.0743 \\
\hline IFRS_KA & 0.024682 & 0.005248 & 4.702939 & 0.0000 \\
\hline $\begin{array}{c}\text { COMPLX_ } \\
\text { KA }\end{array}$ & 0.010884 & 0.011074 & 0.982836 & 0.3271 \\
\hline PROB_KA & -0.001198 & 0.008973 & -0.133539 & 0.8939 \\
\hline ROA & 0.346922 & 0.048185 & 7.199819 & 0.0000 \\
\hline SIZE & 0.187776 & 0.011185 & 16.78829 & 0.0000 \\
\hline
\end{tabular}


Sumber: Hasil pengolahan data dengan Eviews

\section{Uji Statistik Model}

Berdasarkan tabel di atas dapat dibentuk persamaan regresi panel dengan formula sebagai berikut :

$\mathrm{DA}=-3,875178-0,003097$ IFRS $-0,007293$

COMPLX+0,007755

PROB-0,017157

$\mathrm{KA}+0,024682$

IFRS_KA+0,010884

COMPLX_KA-0,001198

PROB_KA+

$0,346922 \mathrm{ROA}+0,187776 \mathrm{SIZE}$

\section{Uji Koefisien Determinasi}

Tabel 5

Uji Koefisien Determinasi

\begin{tabular}{|l|r|}
\hline & Effects Specification \\
\hline Cross-section fixed (dummy variables) \\
\hline & Weighted Statistics \\
\hline R-squared & 0.840633 \\
\hline Adjusted R-squared & 0.748876 \\
\hline
\end{tabular}

Sumber: Hasil pengolahan data dengan Eviews

Hasil estimasi pada tabel, diketahui bahwa nilai adjused $R$-squared yang diperoleh sebesar 0,748876 Hal ini mengindikasikan bahwa kontribusi variabel independen terhadap variabel dependen sebesar 74,88\%. dan sianya sebesar $25.12 \%$ ditentukan oleh variabel lain yang tidak dianalisis dalam model pada penelitian ini.

\section{Uji Simultan (Uji F)}

Tabel 6

Uji Simultan

\begin{tabular}{|l|c|}
\hline & \multicolumn{2}{|c|}{ Effects Specification } \\
\hline Cross-section fixed (dummy variables) \\
\hline & Weighted Statistics \\
\hline F-statistic & 9.161543 \\
\hline Prob(F-statistic) & 0.000000 \\
\hline
\end{tabular}

Sumber: Hasil pengolahan data dengan

Eviews
Berdasarkan tabel diatas dapat dilihat bahwa probabilitas (F-statisic) yang diperoleh sebesar 0.000000 lebih kecil dari sig $(0,05)$. Hal ini menandakan bahwa model regresi diterima dan secara bersama-sama variabel independen mempengaruhi variabel dependen dan model regresi yang dihasilkan sudah fit atau sesuai.

\section{Uji Parsial (Uji t)}

Tabel 7

Uji Parsial

\begin{tabular}{|c|c|c|c|c|c|}
\hline Variable & Coefficient & Std. Error & t-Statistic & $\begin{array}{c}\text { Prob. } \\
\text { Two } \\
\text { Tailed }\end{array}$ & $\begin{array}{c}\text { Prob. } \\
\text { One } \\
\text { Tailed }\end{array}$ \\
\hline C & -3.875178 & 0.231706 & -16.72456 & 0.0000 & 0.00000 \\
\hline IFRS & -0.003097 & 0.000900 & -3.440654 & 0.0007 & 0.00035 \\
\hline COMPLX & -0.007293 & 0.002327 & -3.134135 & 0.0020 & 0.00100 \\
\hline PROB & 0.007755 & 0.001602 & 4.839393 & 0.0000 & 0.00000 \\
\hline KA & -0.017157 & 0.009551 & -1.796428 & 0.0743 & 0.03715 \\
\hline IFRS_KA & 0.024682 & 0.005248 & 4.702939 & 0.0000 & 0.00000 \\
\hline $\begin{array}{c}\text { COMPLX } \\
\text { KA }\end{array}$ & 0.010884 & 0.011074 & 0.982836 & 0.3271 & 0.16355 \\
\hline PROB_KA & -0.001198 & 0.008973 & -0.133539 & 0.8939 & 0.44695 \\
\hline ROA & 0.346922 & 0.048185 & 7.199819 & 0.0000 & 0.00000 \\
\hline SIZE & 0.187776 & 0.011185 & 16.78829 & 0.0000 & 0.00000 \\
\hline
\end{tabular}

Sumber: Hasil pengolahan data dengan

Eviews

\section{Pengujian Hipotesis I : Konvergensi IFRS}

\section{Berpengaruh Negatif terhadap Manajemen Laba}

Berdasarkan tabel diatas diketahui bahwa koefisien konvergensi IFRS bernilai negatif sebesar -0,003097, nilai thitung sebesar 3,440654 dan nilai signifikansi $0.00035<$ 0,05 . Sehingga dapat disimpulkan bahwa konvergensi IFRS berpengaruh negatif terhadap manajemen laba. Dengan demikian hipotesis pertama yang menyatakan bahwa konvergensi IFRS berpengaruh negatif terhadap manajemen laba dapat diterima. 
Pengujian Hipotesis II : Kompleksitas Akuntansi Berpengaruh Positif terhadap Manajemen Laba

Berdasarkan tabel diatas diketahui bahwa koefisien kompleksitas akuntansi bernilai negatif sebesar $-0,007293$, nilai thitung sebesar 3,134135 dan nilai signifikansi $0.00100<0,05$. Sehingga dapat disimpulkan bahwa kompleksitas akuntansi tidak berpengaruh terhadap manajemen laba. Dengan demikian hipotesis kedua yang menyatakan bahwa kompleksitas akuntansi berpengaruh positif terhadap manajemen laba tidak dapat diterima (ditolak).

Pengujian Hipotesis III : Probabilitas Kebangkrutan Perusahaan Berpengaruh Positif terhadap Manajemen Laba

Berdasarkan tabel diatas diketahui bahwa koefisien probabilitas kebangkrutan bernilai positif sebesar 0,007755 , nilai thitung sebesar 4,839393 dan nilai signifikansi $0.00000<$ 0,05 . Sehingga dapat disimpulkan bahwa probabilitas kebangkrutan perusahaan berpengaruh positif terhadap manajemen laba. Dengan demikian hipotesis ketiga yang menyatakan bahwa probabilitas kebangkrutan berpengaruh positif terhadap manajemen laba dapat diterima.

Pengujian Hipotesis IV : Komite Audit Berpengaruh Negatif terhadap

\section{Manajemen Laba}

Berdasarkan tabel diatas diketahui bahwa koefisien komite audit bernilai negatif sebesar $-0,017157$, nilai thitung sebesar 1,796428 dan nilai signifikansi $0.03715<0,05$. Sehingga dapat disimpulkan bahwa komite audit berpengaruh negatif terhadap manajemen laba. Dengan demikian hipotesis keempat yang menyatakan bahwa komite audit berpengaruh negatif terhadap manajemen laba dapat diterima.

Pengujian Hipotesis V : Komite Audit Memperkuat Pengaruh Konvergensi IFRS terhadap Manajemen Laba

Berdasarkan tabel diatas diketahui bahwa koefisien interaksi konvergensi IFRS dan komite audit bernilai positif sebesar 0,024682, nilai thitung sebesar 4,702939 dan nilai signifikansi $0.00000<0,05$. Sehingga dapat disimpulkan bahwa komite audit tidak memperkuat pengaruh konvergensi IFRS terhadap manajemen laba. Dengan demikian hipotesis kelima yang menyatakan bahwa komite audit memperkuat pengaruh konvergensi IFRS terhadap manajemen laba tidak dapat diterima (ditolak).

Pengujian Hipotesis VI : Komite Audit Memperlemah Pengaruh Kompleksitas Akuntansi terhadap Manajemen Laba.

Berdasarkan tabel diatas diketahui bahwa koefisien interaksi kompleksitas akuntansi dan komite audit bernilai negatif sebesar 0,000693, nilai thitung sebesar 0,080940 dan nilai signifikansi $0.16355>0,05$. Sehingga dapat disimpulkan bahwa komite audit tidak memperlemah pengaruh kompleksitas akuntansi terhadap manajemen laba. Dengan demikian hipotesis keenam yang menyatakan bahwa komite audit memperlemah pengaruh 
kompleksitas akuntansi terhadap manajemen laba tidak dapat diterima (ditolak).

Pengujian Hipotesis VII : Komite Audit Memperlemah Pengaruh Probabilitas Kebangkrutan Perusahaan terhadap Manajemen Laba.

Berdasarkan tabel diatas diketahui bahwa koefisien interaksi probabilitas kebangkrutan perusahaan dan komite audit bernilai negatif sebesar -0,001482, nilai thitung sebesar 0,122729 dan nilai signifikansi $0.44695>$ 0,05 . Sehingga dapat disimpulkan bahwa komite audit tidak memperlemah pengaruh probabilitas kebangkrutan terhadap manajemen laba. Dengan demikian hipotesis ketujuh yang menyatakan bahwa komite audit memperlemah pengaruh probablitas kebangkrutan terhadap manajemen laba tidak dapat diterima (ditolak).

\section{PENUTUP}

\section{Kesimpulan}

Berdasarkan pada hasil analisis dan pembahasan yang telah dilakukan, dan untuk menjawab tujuan penelitian yang diajukan maka dapat diambil simpulan : 1) IFRS berpengaruh negatif terhadap manajemen laba; 2) Kompleksitas akuntansi tidak berpengaruh terhadap manajemen laba; 3) Probabilitas kebangkrutan perusahaan berpengaruh positif terhadap manajemen laba; 4) Komite audit berpengaruh negatif terhadap manajemen laba; 5) Komite audit tidak memperkuat pengaruh konvergensi IFRS terhadap manajemen laba; 6) Komite audit tidak memperlemah pengaruh kompleksitas akuntansi terhadap manajemen laba; 7) Komite audit tidak memperlemah pengaruh probabilitas kebangkrutan perusahaan terhadap manajemen laba.

\section{Keterbatasan}

Adapun keterbatasan dalam penelitian ini yang mungkin mempengaruhi hasil penelitian adalah: 1) Terdapat beberapa perusahaan tidak menampilkan beberapa informasi mengenai variabel-variabel yang ada dalam penelitian secara lengkap sehingga mengurangi jumlah sampel; 2) Terdapat beberapa perusahaan yang annual reportnya tidak ditemukan di website Bursa Efek Indonesia selama periode pengamatan sehingga harus dihapuskan dari sampel penelitian; 3) Adanya permasalahan dalam melakukan uji asumsi klasik, yaitu tidak terpenuhi uji heteroskedastisitas dan uji autokorelasi sehingga dilakukan transformasi fix effect model dengan menggunakan pendekatan Panel-Corrected Standard Errors (PCSE), dimana metode ini akan mengatasi masalah heteroskedastisitas dan autokorelasi.

\section{Saran}

Adapun saran yang dapat diberikan dalam penelitian ini adalah: 1) Penelitian yang akan datang diharapkan dapat menambah varian sampel, tidak hanya perusahaan manufaktur saja, tetapi juga dengan menggunakan industri lain, seperti keuangan, jasa dan sebagainya; 2) Penelitian mendatang disarankan mengunakan rentang waktu yang lebih panjang untuk bisa menggeneralisasi hasil penelitian; 3) Penelitian mendatang 
menggunakan faktor-faktor lain yang dapat mempengaruhi manajemen laba, sehingga hasil yang diperoleh akan lebih akurat. Seperti leverage, growth, jenis industri, kualitas audit, arus kas operasi, dan sebagainya.

\section{DAFTAR PUSTAKA}

Abaoub, E. and Nouri, Y., 2015. Earnings management and analyst coverage changes around IFRS implementation: Evidence from France. The International Journal of Business and Finance Research, 9(3), pp.83-94.

Aryati, T. and Walansendouw, Y.C., 2013. Analisis Pengaruh Diversifikasi Perusahaan Terhadap Manajemen Laba. Jurnal Akuntansi dan Auditing, 9(2), pp.244-260.

Ayemere, I.L. and Elijah, A., 2015. Audit committee attributes and earnings management: Evidence from Nigeria. International Journal of Business and Social Research, 5(4), pp.14-23.

Cahyati, A.D., 2011. Peluang manajemen laba pasca konvergensi IFRS: Sebuah tinjauan teoritis dan empiris. JRAK: Jurnal Riset Akuntansi \& Komputerisasi Akuntansi, 2(01), p.4454.

Daniswara, R. and Kiswara, E., 2015. PENGARUH KONVERGENSI INTERNATIONAL FINANCIALREPORTING STANDARDS DANAUDIT DELAY (Studi Empiris pada Perusahaan Manufaktur yang Terdaftar di Bursa Efek Indonesia) (Doctoral dissertation, Fakultas Ekonomika dan Bisnis).

Dinuka, V.K. and Zulaikha, Z., 2014. Analisis Pengaruh Audit Tenure, Ukuran KAP dan Diversifikasi Geografis terhadap Manajemen Laba (Doctoral dissertation, Fakultas Ekonomika dan Bisnis).

Dyreng, S.D., Hanlon, M. and Maydew, E.L., 2012. Where do firms manage earnings?. Review of Accounting Studies, 17(3), pp.649-687.

Fahmi, I., 2011. Analisis laporan keuangan.
Fathoni, A.F. and Wijaya, E.Y., 2014. The Effect Of Good Corporate Governance Mechanism, Financial Distress On Earning Management Behavior: Empirical Study In Property And Infrastructure Industry In Indonesian Stock Exchanges. Jurnal Ekonomi, 22(01), pp.116-131.

Firdaus, M., 2011. Aplikasi ekonometrika untuk data panel dan time series.

Gujarati, D.N., 2006. Dasar-dasar Ekonometrika Jilid 1 dan 2. Edisi Ketiga. Erlangga. Jakarta.

Hadi, S. and Anggraeni, A., 2008. Pemilihan Prediktor Delisting Terbaik (Perbandingan Antara The Zmijewski Model, The Altman Model, dan The Springate Model). Jurnal Akuntansi dan Auditing Indonesia, 12(2).

Hermiyetti, H. and Manik, E.N., 2013. The influence of good corporate governance mechanism on earnings management: empirical study in Indonesian stock exchange listed company for periods of 2006-2010. Indonesian Capital Market Review.

Hildebrand, A.J., 2008. Actuarial Statistics I, Urbana, USA.

Indraswari, R., 2009. Pengaruh status internasional diversifikasi operasi dan legal origin terhadap manajemen laba: Studi perusahaan Asia terdaftar di NYSE (Doctoral dissertation, [Yogyakarta]: Universitas Gadjah Mada).

Jao, R. and Pagalung, G., 2011. Corporate governance, ukuran perusahaan, dan leverage terhadap manajemen laba perusahaan manufaktur Indonesia. Jurnal akuntansi dan auditing, 8(1), pp.43-54.

Jensen, M.C. and W.H. Meckling., 1976. Theory of Firm: Managerial Behaviour, Agency Costs and Ownership Structure. Journal of financial economics 3, 305-360.

Kasmir. 2014. Analisis Laporan Keuangan. $1^{\text {st }}$. Cetakan Ketujuh. Jakarta: PT Raja Grafindo Persada.

Kusumayani, N.L. and Wirama, D.G., 2016. Good corporate governance sebagai pemoderasi pengaruh diversifikasi operasi dan diversifikasi geografis pada manajemen laba. E-Jurnal Akuntansi, 14(3), pp.2072-2102. 
Lin, J.W., Li, J.F. and Yang, J.S., 2006. The effect of audit committee performance on earnings quality. Managerial Auditing Journal.

Lupitasari, D. and Marsono, M., 2013. Diversifikasi perusahaan dan manajemen laba. Diponegoro Journal of Accounting, pp.118-129.

Marra, A., Mazzola, P. and Prencipe, A., 2011. Board monitoring and earnings management pre-and post-IFRS. The International Journal of Accounting, 46(2), pp.205-230.

Mehdi, I.K.E. and Sebou, S., 2011. Corporate Diversification and Earnings Management. Review of Accounting and Finance, 10(2): 176-196.

Munawir, S., 2008. Analisis Informasi Keuangan. Yogyakarta: Liberty Yogyakarta.

Nurazmi, H., Lilik and Efendy, L. 2015. Dampak Adopsi IFRS terhadap Manajemen Laba serta Peran Mekanisme Corporate Governance pada Perbankan Indonesia. Simposium Nasional Akuntansi 18 Universitas Sumatera Utara, Medan. 121.

Peraturan Otoritas Jasa Keuangan Nomor 55/Pojk.04/2015 Tentang Pembentukan dan Pedoman Pelaksanaan Kerja Komite Audit.

Qomariah, R.N. and Marsono, M., 2013. Dampak Konvergensi IFRS terhadap Manajemen Laba dengan Struktur Kepemilikan Manajerial sebagai Variabel Moderating (Studi Empiris pada Perusahaan Manufaktur yang Terdaftar di Bursa Efek Indonesia Tahun 2009. 2012) (Doctoral dissertation, Fakultas Ekonomika dan Bisnis).

Sarwono, J., 2016. Prosedur-prosedur Analisis Populer Aplikasi Riset Skripsi dan Tesis dengan Eviews. Jakarta: Gava Media.

Satoto, H.S., 2007. Strategi Diversifikasi terhadap Kinerja Perusahaan. Jurnal Keuangan dan Perbankan, 13(5): 280287.

Scott, W.R., 2015. Financial Accounting Theory. Seventh Edition. Canada. Pearson Canada Inc.
Subramanyam, K.R. and Wild, J.J., 2013. Analisis Laporan Keuangan. Edisi 10, Buku 2. Jakarta: Salemba Em

Sugiyono. 2014. Metode renelitian Kuantitatif, Kualitatif dan Kombinasi (Mixed Methods). Bandung: Alfabeta.

Sulistiawan, D. and Januarsi, Y., 2011. Creative accounting: mengungkap manajemen laba dan skandal akuntansi.

Sulistyanto, S., 2008. Manajemen Laba: Teori dan Model Empiris. Grasindo: Jakarta.

Surat Edaran Otoritas Jasa Keuangan Nomor 32 /Seojk.04/2015 Tentang Pedoman Tata Kelola Perusahaan Terbuka.

Sutedi, A., 2011. Good Corporate Governance. Jakarta: Sinar Grafika.

Widyawati, A.A. and Anggraita, V., 2013. Pengaruh konvergensi, kompleksitas akuntansi, dan probabilitas kebangkrutan terhadap timeliness dan manajemen laba. Jurnal Akuntansi Dan Auditing Indonesia, 17(2), pp.135-155.

Wulandari, W.A. and Lastanti, H.S., 2015. PENGARUH KONVERGENSI IFRS EFFEKTIF TAHUN 2012, KOMPLEKSITAS AKUNTANSI DAN PROBABILITAS KEBANGKRUTAN PERUSAHAAN TERHADAP TIMELINESS DAN MANAJEMEN LABA PADA PERUSAHAAN MANUFAKTUR YANG TERDAFTAR DI BURSA EFEK INDONESIA. Jurnal Akuntansi Trisakti, 2(1), pp.67-88.

www.idx.co.id www.sahamok.com Perusahaan Manufaktur di Bursa Efek Indonesia (BEI). 2007. Dasar-dasar Ekonometrika. Jakarta: Erlangga. 